\title{
Reducing Anchorage in Ports: Changing Technologies, Opportunities and Challenges
}

\author{
Trevor D. Heaver* \\ Sauder School of Business, University of British Columbia, Vancouver, BC, Canada
}

Developments in digitisation and the need to reduce carbon emissions have increased attention on port call optimisation. Just-in-time arrival for ships is recognised in the literature as being achieved more readily in container trades than in bulk trades. This paper examines the governance and trade logistics conditions in the bulk trades of Vancouver, Canada, as the increasing number of ships at anchor gives rise to the need to explore the absence of initiatives to limit anchorage and to identify what is done elsewhere to manage the incidence of anchorage. Newcastle, Australia, is used to identify critical governance and logistics factors that played a role in the development of innovative practices to reduce anchorage. The major obstacles to port call optimisation lie in the organisational and behavioural aspects of maritime logistics, not in the technology of digitisation.

\section{OPEN ACCESS}

Edited by:

Edwin Van Hassel,

University of Antwerp, Belgium

Reviewed by:

Marcella De Martino,

Research Institute on Innovation and Development Services (IRISS), Italy

Thierry Vanelslander,

University of Antwerp, Belgium

*Correspondence:

Trevor D. Heaver

Trevor.heaver@sauder.ubc.ca

Specialty section:

This article was submitted to Freight Transport and Logistics,

a section of the journal

Frontiers in Future Transportation

Received: 14 May 2021

Accepted: 15 July 2021

Published: 28 July 2021

Citation:

Heaver TD (2021) Reducing Anchorage in Ports: Changing

Technologies, Opportunities and Challenges.

Front. Future Transp. 2:709762. doi: 10.3389/ffutr.2021.709762
Keywords: maritime logistics, vurtual arrival clause, port call optimisation, port governance, managing anchorage

\section{INTRODUCTION}

The period that the world has grappled with the Covid pandemic has put a spotlight on change. This is evident in ports where the digital revolution has created new opportunities for improved performance in logistics chains to the benefit of the economy and the environment. The reduction of anchorage through port call optimisation (PCO) is a realistic goal.

Periods of change are commonly driven by the interaction of innovations in technology with human ingenuity. Such was the case fifty years ago as logistics management transitioned from a military concept to industrial practice and subsequently morphed into supply chain management. Comparable changes are imminent now as digitisation holds the promise of gains but demands new levels of cooperation involving intergovernmental organizations, governments and port authorities as well as industry stakeholders in maritime trade and logistics, World Bank (2020).

Digitisation is the key enabler and driver as it leads to heightened supply chain visibility and new decision-making processes. But effective change is not just a matter of technology. More importantly, it requires changes in perceptions, attitudes and political commitments across corporate, nongovernmental and governmental organisations. The human dimensions of innovation are often more difficult to resolve than the technical ones, Waters (1973).

The varied adoption of digitisation triggered a call to action communiqué by leading port and shipping industry organisations, World Ports Sustainability Program (WPSP, 2020). The call for action sets out nine priority areas for action to advance digitisation in ports. One of these is to "Raise awareness, avoid misconceptions, standardize and promote best practices as to how port communities can apply emerging technologies".

This paper contributes to the work of promoting digitisation by investigating factors contributing to levels of anchorage in dry bulk trades. Reduced anchorage has too often been 
treated as a by product of other objectives, such as reducing greenhouse gas (GHG) emissions, rather than as and itself. The focus here is on anchorage in ports with substantial dry bulk trades because the challenges of achieving change are great as a result of the diversity of corporate interests and logistics conditions, IMO (2020).

The absence of studies focused on reducing anchorage in such ports warrants an investigatory research approach to identify the port governance and commodity logistics conditions that affect the adoption of measures to improve the management of the level of anchorage. The port of Vancouver is used as a case study as the level of anchorage has been increasing for some time and has become a political issue, Transport Canada (2018). To provide perspective and to gain insights on the conditions in Vancouver, the experience in the coal trade of Newcastle, Australia is reviewed as, since 2010, that port has been successful in managing the logistics of export coal with greatly diminished levels of anchorage.

Examination of conditions affecting anchorage in the two ports requires attention to many governance and logistics factors that affect anchorage. The breadth of the coverage and the confidentiality of contractual arrangements precludes detailed analyses. Nevertheless, the experience in the dry bulk trades of these ports provides an opportunity to identify challenges to the adoption of measures to reduce anchorage and to identify strategies to advance their adoption.

The concern with anchorage is akin to the recognition by Toyota over 50 years ago of inventory as an indicator of inefficiency in manufacturing. Toyota introduced new business concepts and practices to reduce inventories including just-in-time (JIT) product availability. JIT is now a widely recognised strategy although rarely achievable in a pure form. The goal in port logistics may be captured by the term "fluidity" under which intermodal transfers take place with only efficient levels of equipment delays and product inventories. ${ }^{1}$

The paper is in six sections. As the need to decrease vessel anchorage is an important driver of PCO, the next section reviews the literature on and related to anchorage. The third section reviews developments in digitisation for PCO and the rapid development of companies providing related digital services. In section four, Vancouver is used as a case study to describe the structural, contractual and policy conditions affecting logistics and anchorage in a port which is not pursuing a PCO strategy. The experience in Newcastle is summarised in section five to identify conditions that facilitated change there and may carry lessons for Vancouver and other ports. The final section draws on the conditions in the two ports to identify challenges to reducing anchorage and to suggest strategies that may lead to improved performance.

${ }^{1}$ The term fluidity is used in the social and physical sciences in reference to changes or movements that take place as pressures or opportunities for change occur. The term has been used in Canadian transport, Tardif (2010) and many annual reports of Canadian National Railway (2006), and recognised by the Transportation Research Board (2018).

\section{LITERATURE REVIEW}

The anchorage of ships normally gets attention when supply chains are not working well and ships line up at ports, as is happening in too many container trades in 2021. This and other crisis times are not dealt with here although the waiting ships demonstrate that ships at anchor are commonly the evidence of logistics problems along the chain. Ships at anchor are equivalent to the spots that are evidence of measles.

Some ships at anchor in ports are commonly taken as business as usual; a necessary inventory to accommodate the uncertainty of ship arrivals in light of variable ocean and port conditions. This may account for academic articles on anchorage dealing not with the economics of ships at anchor but with their safety, the utilisation of areas for anchorage, Zhong and Ai (2017) and $\mathrm{Oz}$ et al. (2015), and the effects of anchorage on the marine ecosystem, Broad et al. (2020). Studies modelling aspects of port terminal operations and performance, usually container terminals, do not examine the effects of management practices on the level of anchorage, Golias et al. (2009), Legato and Mazzo (2020). Attention to anchorage has arisen from the interest in strategies to save fuel and to reduce GHGs.

The virtual arrival clause (VA) was developed for charter parties to enable slow steaming when there was a known delay at the discharge port, INTERTANKO (2011), BIMCO (2013). The potential reduction in fuel consumption and emissions from the application of VA have been studied, for example by Jia et al. (2017) and Hensel et al. (2020). Although VA has not been widely adopted even in oil trades and seems absent from dry bulk trades, renewed interest is evident because of the need to reduce GHGs, BIMCO (2021).

The Global Industry Alliance to Support Low Carbon Shipping (GIA, 2020) of the International Maritime Organisation (IMO) outlines a broad approach to reduce GHG emissions in its "Just In Time Arrival Guide-Barriers and Potential Solutions," IMO (2020). It is an important document as it outlines the full range of decisions in supply chains that affect port call optimization and therefore the level of anchorage. However, the Guide recognises JIT arrival is most likely to be realised for scheduled services such as container services for which the (normal) availability of containers to load can be assumed. The Guide does not deal with issues of inland logistics which are vital in bulk trades for which specific cargoes have to be available for specific vessels (Bruijn, 2021).

The literature and management practices in the last decade reflect the opportunities advanced by digitisation and, for shipping, the requirement by the IMO that all cargo ships over 300 gross tons in international trade be AIS capable by December 31 2004. AIS data has enabled much new research in shipping. Hensel et al. (2020) note the many studies estimating emissions for particular vessels in specific areas and outline a methodology for global measurement. Jahn and Scheidweiler (2018) use AIS and vessel data to develop a predictive model of vessel speed to derive improved estimates of vessel arrival times for German North and Baltic Sea ports.

Pursuing the goal of reducing greenhouse gases (GHGs) from ships results in attention being given primarily to vessel 
operations. Little attention is given to factors in cargo logistics that give rise to the need for vessels to anchor. The main insight for anchorage from the emissions literature is the consideration of factors that inhibit the adoption of slow steaming and, therefore, result in the persistence of anchorage. The dominant among them are the contractual terms in charter parties followed by the firstcome-first-served policy of some terminals, Rehmatulla (2012). Kontovas and Psaraftis (2013) present the problems preventing the adoption of the win-win approaches to emissions reduction in the more formal context of the principal-agent problem. BIMCO has issued a 2021 JIT charter party clause to address the effect on ships under voyage charter that they should "proceed with due or utmost despatch and without deviation" BIMCO (2021). This normally applies to loaded ships. The literature has not dealt with the ships proceeding in ballast to arrive (give their Notice of Readiness) within the laycan period of the charter party, as occurs in exporting trades. ${ }^{2}$

More detailed and operational insights into the challenges of emission reduction by port call optimisation are provided by the qualitative research of Johnson and Styhre (2015) and Poulsen and Sampson (2019), Poulsen and Sampson (2020). They report, on the basis of ship records and interviews and sailing on two ships and interviews, on the variety of commercial and operational matters inhibiting the use of VA and the optimal timing of port operations. Prominent among the obstacles is a lack sharing of real-time traffic information among port stakeholders. Poulsen and Sampson (2020) observe that "best practices might be present when the same company owns terminals and cargoes and/or ships and ensures port stakeholder coordination."

\section{DEVELOPMENTS IN PORT DIGITISATION}

The momentum of digitised real-time information systems in ports is unfolding in waves. There are many organisations addressing innovations in ports; UNCTAD (2020) has a nonexhaustive list of fifteen initiatives including International Taskforce Port Call Optimization (ITPCO), the International Port Community Systems Association (IPCSA), and the International Port Collaborative Decision-Making Council (IPCDMC). The concept of the smart port is institutionalised in the Smart Ports Entrepreneurial Ecosystem Development (SPEED) project which aims to improve ports in Belgium, France, the Netherlands and the United Kingdom by using new advances in technology and data science. The Resilience Shift project aims to advance the provision of port infrastructures, including information, to advance port communities, Davey et al. (2021).

There are also many new technology companies that have developed hardware and software systems for market segments, Zion Market Research (2021). These include services to facilitate

${ }^{2}$ Laycan is the period during which a ship must be available to load. If it misses this period, the charter may be cancelled. On giving Notice of Readiness the free time for loading starts under the charter party terms. optimisation of vessel routing and speed using real-time information on many environmental and economic conditions; examples are Nautilus Labs and TerraVision. There are also services, for example PortLink, that focus on port information systems appropriate for vessel traffic management systems. New services are available to ships and terminals to calculate estimated time to complete (ETC) loading, for example, United Kingdom.based CargoMate of Intelligent Cargo Systems. NxtPort in Antwerp offers a platform of services for sharing data between different port players. MGI, a logistics company founded in Marseille, has developed a system to manage goods flows in port, airport and inland logistics communities.

European ports are hosts to initiatives advancing port call optimisation. Lind et al. (2016) presented a paper in Vancouver to advocate the adoption of port collaborative decision making (PortCDM) to overcome poor predictability about the timing of events in ports. (Vancouver is still lagging) PortCDM is a concept of sharing time data related to port calls in real time to facilitate increased efficiency in just-in-time arrivals, berth productivity, reduce waiting and anchoring times. The concept has been tested in several European ports under the Sea Traffic Management Validation Project co-financed by the European Union and numerous corporations, STM (2017), STM (2021). The Port of Rotterdam commercialised its Pronto system into PortXchange. The Port of Antwerp has developed Antwerp Port Information and Control System (APICS). The Hamburg Port Authority initiated ChainPORT to work with other leading ports to share knowledge about new opportunities for taking advantage of digitisation, Hamburg (2019). Wärtsilä successfully implemented its Navi-Port system for the arrival and berthing of a cruise ship in Hamburg, Wärtsilä (2020). The development and application of such systems for port call optimisation is advanced by a report on digitisation by the World Bank (2020).

The progress of digitisation and port call optimisation in Europe is notable. Many factors contribute to this. They include the interest of the local port authorities in efficient logistics, the importance of short-sea shipping, the support of governments and the European Union for transport innovation, and the presence of leading technology firms. Such conditions do not come together in Vancouver but, in light of the developments elsewhere, it seems likely that there are particular conditions inhibiting change.

\section{VANCOUVER CASE STUDY}

Port governance is the institutional framework within which the infrastructure and services needed by commodity trades are provided. It is examined prior to describing the nature of the trades and experience of Vancouver with anchorage.

\section{The Governance Structure and Administrative Practices}

The governance structure in Vancouver has a number of attributes that slow the adoption of digitalisation in a port community system. They include: 
- The divided responsibility for the communication with ships between the Vancouver Fraser Port Authority (VFPA), Transport Canada (TC), the Pacific Pilotage Authority (PPA) and the Canadian Coast Guard (CCG);

- The divided responsibility for anchorages between VFPA and TC and the limited management of remote anchorages;

- Initiatives to improve logistics system performance have focused on land-based improvements and on container trades;

- The VFPA has had no interest in community-based information systems. Today, jurisdictional issues are cited as an obstacle.

The fragmented governance structure of services for ships arriving in Vancouver goes beyond the usual government departments dealing with health and safety, immigration, and agriculture. ${ }^{3}$ The public jurisdiction for services to ships is divided. The VFPA is a federal non-shareholder corporation established by the Government of Canada to manage the lands and waters under its jurisdiction. It can be regarded as a landlord port. It assigns vessels to anchorages. Pilotage for the whole coast is administered by the PPA, a federal crown corporation. TC has jurisdiction for navigation in all coastal waters; this is managed by the CCG through its Marine Communications and Traffic Services (MCTS). ${ }^{4}$ MCTS provides vessel navigation services by exchanging information between ships and its centre in Victoria. While TC has a regional director in Vancouver, all responsibility for the anchorage file resides in Ottawa, some $3,500 \mathrm{kms}$ distant. Continental and national initiatives related to port call optimisation that might prompt innovation in ship services comparable to Europe are absent.

The mandate of VFPA is to facilitate trade while ensuring safety, environmental protection and consideration for local communities. The port authority must be financially selfsufficient. The VFPA has 28 deep-sea anchorages within its waters. Typically, VFPA gets pre-arrival notification from ships $24 \mathrm{~h}$ prior to their expected arrival. If needed, it assigns vessels to these anchorages and monitors their activities. In waters beyond VFPA, TC has jurisdiction for anchorage.

For several years prior to 2018, VFPA sent vessels expected to spend more than seven days in its anchorages to anchor some 40 nautical miles distant in the Gulf Islands. There was no formal process by which vessels were allocated to specific anchorages. It was hoped that extra sailing costs would deter long anchorages. However, the use of anchorages in southern B.C. increased and became controversial, Pynn (2018). Concerns were voiced by the Islands Trust (2018).

Responding to concerns about the use of these anchorages, studies and consultations were conducted under TC's Ocean Protection plan. The Interim Protocol for the use of Southern B.C. Anchorages, was issued by TC, February 8, 2018. The VFPA agreed to assign vessels to these anchorages on the basis of information available to it, to balance the usage of anchorages,

${ }^{3}$ Public Safety Canada, Canada Border Services Agency and Agriculture Canada. ${ }^{4}$ The Canadian Coast Guard reports to the minister of Fisheries and Oceans. subject to individual anchorage size restrictions and taking into account anchorage usage over the previous 30 days. The VFPA requires MCTS to distribute weather forecasts for vessels anchored under its jurisdiction when the wind speed is more than 25 knots. TC has no such requirement for the vessels under its jurisdiction, TSB (2021). VFPA compiles data of the vessels at its anchorages; no such data is compiled for other anchorages.

As a landlord port authority, the focus of the VFPA has been on the best use of its properties and the quality of the infrastructure and related services that are integral to the terminals' trade. Three strategies have been evident. The first has been to engage in activities beyond its physical land boundaries to improve logistics services. Examples are investment in community infrastructure to improve access to the port and a short-term ownership in an off-dock freight handling service. The second has been setting standards for operations on its terminals, for example, setting standards for drayage trucks and installing vehicle tracking technology on these vehicles. These interventions were taken to initially to mitigate the prospect of disruptions to drayage service. The third has been done jointly with TC to provide better information about current port traffic conditions so that short-run and long-run decisions by companies are better informed. This is currently done through the Supply Chain Visibility Program which provides rail, truck, terminal and vessel metrics for container transport. The program has not been able to extend to bulk commodities.

The port authority has not participated in port community information systems. In the 1980s, it declined to initiate discussion of electronic data interchange (EDI) within the port community. Currently, implementation of a maritime single window for ports is seen as a national responsibility for which TC is the lead department, (VFPA, personal communication). Canada has not complied with the Convention on Facilitation of International Maritime Traffic, effective in 2019 and no progress is evident. However, VFPA has a sophisticated operations centre with technology oriented to monitoring truck movements and vessel anchorage within its waters.

The obstacles to change created by the divided responsibilities of public bodies are compounded by the diversity of interests among corporations. This arises from the different interest of companies across and within commodity chains.

\section{The Port's Trade and Anchorage Record}

Vancouver has very diversified trades which contributes to the complexity of managing its resources, including the anchorages. In 2019, its international bulk trade was 83 million tonnes of which 80 million tonnes were exported; the container trade tonnage was 12.1 and 14.8 million tonnes imported and exported respectively carried in 1.7 and 1.1 laden containers. Three commodity group accounted for $92 \%$ percent of the bulk tonnage exports; coal 37.8, grain 23.9 and fertiliser 11.9 million tonnes.

There is no official record of overall anchorage days for Vancouver as VFPA only has data for vessels at anchorages within its waters. An unpublished study of all vessel anchorages for vessels visiting the port of Vancouver indicated that between January 2013 and August 201849 and 32\% of total 
TABLE 1 | Ships, average cargo, anchorage and berth time by commodity, 2015-2018

\begin{tabular}{lccc}
\hline & Grain & Coal & Fertilisers \\
\hline Av annual \# ships & & & \\
Average ship cargo $^{\mathrm{a}}$ & 483 & 336 & 210 \\
Av berth days $^{\mathrm{a}}$ & 46,113 tonnes & 105,892 & 51,283 \\
Av anchor days $^{\mathrm{b}}$ & 4.3 & 2.6 & 2.9 \\
Av total anchor days $^{\mathrm{c}}$ & 10.0 & 6.9 & 3.7 \\
& 4,830 & 2,318 & 777
\end{tabular}

${ }^{a}$ Own calculation based on VFPA data by correspondence.

${ }^{b}$ Rohner and Fullerton, 2020 and by correspondence.

${ }^{c}$ VFPA number of ships multiplied by Rohner and Fullerton average anchor days.

anchorage days were attributable to vessels in the grain trade and in the coal and potash trades respectively. ${ }^{5}$ Container vessels and cruise ships rarely anchor and the limited anchorage of tankers is dominantly adjacent to the oil terminal.

The following data on anchorage in dry bulk exports are from two sources. The first is Rohner and Fullerton (2020) who use detailed pilotage records. The second is unpublished anchorage data for dry bulk vessels at VFPA anchorages made available to the author by VFPA.

There is a significant variation in the incidence of anchorage by commodity evident in the average data for 2015-2018, Table 1. These differences remain comparable under annual variations caused by weather, labour issues and traffic volumes. The grain trade employs the largest number of vessels and those vessels are at anchor and on the berth for the longest average times. The trade with the least time at anchor is the fertilizer group; potash is consistently over $70 \%$ of this group. The coal and fertiliser trades are stable through the year whereas the number of grain ships and their anchorage are seasonal. The number of grain anchor days doubles between August and March, but grain ships account for more anchor days than coal ships for every month. The variation in the need for anchorage by the commodity groups is the result of many logistical conditions.

The easy target for the difference in the incidence of anchorage is industry structure: grain has hundreds of origins in the Canadian prairies; potash and coal each come from a few mines. Grain output is subject to the vagaries of weather; a relevant but not dominant variable.

Asset ownership/control accounts for different levels of visibility and operational integration along the logistics chains. It is greatest for fertilisers and least for grains. The resulting differences in performance contribute to the level of anchorage.

Overseas grain exports are dominated by seven competing companies that have country elevators and port terminals. Grain purchased from farmers is held in country elevators until moved by rail, dominantly in rail-owned cars (wagons) to port terminals. Only the newest elevators and terminals are able to load/unload solid unit train sets of cars. Western Canadian export coal is from five mines owned by Teck Corporation which owns its own sets of

${ }^{5}$ The background study for Transport Canada used pilotage data but did not differentiate between vessels loading at specific coal and potash berths. rail cars. It exports through two terminals in Vancouver; Neptune Terminals in which it owns its storage and loading facilities and Westshore, a common user terminal that also ships some US coal. The fertiliser trade is made up of two potash chains and one sulphur chain. In each chain, the rail cars and the terminal facilities are dedicated to the producer. The largest tonnage and most integrated system is that of Canpotex which owns half of Neptune Terminals and sells dominantly on delivered (CFR) terms. ${ }^{6}$ Shippers in each chain express concerns about the reliability of rail service but this is greatest for grain shippers who also are most affected by poor information on the delivery schedule of car blocks.

The result of the diverse conditions in the trades is that the potential benefits from digitisation vary greatly. Managers in well-integrated chains see little benefit from digitisation especially if it requires them to expose information regarded as confidential. In the grain trade, the competing companies are particularly concerned about processes that may result in sharing or divulging information that they regard as likely to affect their competitiveness. As a result, while they might gain most from digitisation, they are hesitant, at best, to embrace it.

The challenge of product availability in the logistics chains is affected by the diversity of products and the number of SKUs to be inventoried in terminals to serve particular ships. Canpotex and Teck each have the benefit of two port terminals to help manage the inventory of different SKUs. Managing the inventories at terminals is affected by the quality of information on vessel arrival which varies depending on the terms of shipment. The best information flow is exemplified by Canpotex with CFR sales. Grain which used to be just sold on FOB terms, is shifting to more CFR sales but no quantification is possible. Coal is sold dominantly on FOB terms.

The persistence of high levels of anchorage point to the challenges of contracting for sales months ahead of transactions when the logistics are uncertain. Managing the logistics to reduce and tackle the uncertainties would facilitate better contracting schedules. Unfortunately, this is a challenge that is very difficult to meet successfully. The challenge is present too in the Newcastle coal chain but there has been some success in managing it there.

Finally, it has not been possible to research terminal practices in serving vessels. Many factors are taken into account but the first-come-first-served seems to be the norm at, at least, one terminal. This is the least desirable policy for efficient logistics.

\section{THE NEWCASTLE EXPERIENCE}

Newcastle is a coal port; in 2019, coal exports were 165 million tonnes, other commodity exports were less than one million and total imports about five million tonnes. It is under the jurisdiction of the state of New South Wales. Prior to July 2014, the state-owned Newcastle Port Corporation managed port lands and acted as harbourmaster within the port and coastal waters managing

\footnotetext{
${ }^{6}$ Canpotex also owns a terminal in Portland, Oregon.
} 
shipping movements, safety, security and emergency response and providing pilotage services. In 2014, it amalgamated into the Port Authority of New South Wales with responsibility for managing the navigation, security and operational safety needs of commercial shipping and providing pilotage in the port and coastal waters (Hereinafter, both are referred to as NPA.) The NPA reviews bookings and coordinates vessel movements through the Vessel Traffic Information Centre (VTIC). Since 2014, port lands and waterways are on a 98 years lease to Port of Newcastle (PON) owned 50/50 by an Australian and a Chinese infrastructure fund. $\mathrm{PON}$ is responsible for dredging waterways.

In 2004, the Australian Competition and Consumer Commission (ACCC) approved cooperative arrangements between the mines, railways and terminals in the Hunter Valley Coal chain to enable efficiencies in the chain, ACCC (2009a). Nevertheless, increased demand for coal led to congestion in the chain, evident in 2007 with over 70 vessels at anchor on some days, Inbakaran et al. (2008). The beaching of the Pasha Bulker, June 8 2007, brought to a head concerns over the number and time of vessels at anchor and the risks they represented. It was a near black swan event; it was a rare event but fortunately without dire consequences.

Prior to 2010, no record was kept by the NPA of the time for vessels at anchor, ${ }^{7}$ (as is the case for ships outside VFPA waters). Documentation following the Pasha Bulker incident revealed that in 2009 vessels averaged 11.1 days between the time that they joined the queue of anchored vessels and entered the port.

Among the findings of the Australian Transport Safety Bureau, ATSB Australian Transport Safety Bureau (2008) into the beaching of the Pasha Bulker was that "any measure which effectively controls the congestion and reduces the number of ships, waiting at anchor, in the queue also reduces the risks to the ships, the port and the environment." To advance expansion of the coal throughput while reducing anchorage, the New South Wales (NSW) government appointed former Premier Nick Greiner to facilitate improvements in the Hunter Valley coal chain. He involved all parties from the mining companies, the railway companies, the terminals, NPA and the main international buyers and ship owners in his review. Subsequently, on behalf of the NSW government, NPA "largely led" industry discussions resulting in the application and authorisation of the Capacity Framework Arrangements by ACCC, December 9, 2009, effective to the end of 2024, ACCC (2009b).

The outcome was processes by which the mines, railways and terminals cooperate with the Hunter Valley Coal Chain Coordinator Ltd. (HVCCC) which plays a key role in managing capacity allocations. The processes are founded on collaboration and trust, which facilitates efficient contracting with mutual responsibilities and achieves effective visibility to enable responsiveness. ${ }^{8}$ Commercial aspects of contracts remain confidential to the parties involved. A new pull strategy replaced the old push strategy to manage the inventory of coal at port terminals. Not all mines were happy initially. Some feared that a limitation on anchorage would reduce the capacity for

\footnotetext{
${ }^{7}$ Communications with Bruce Cooper, Senior Manager Port Services, Newcastle. ${ }^{8}$ Communications with Bruce Cooper; Sean Boyle, Hunter Valley Coal Chain Coordinator; Brad Belcher, Customer Specialist, Port Waratah Coal Services.
}

exports. Their fears proved wrong as better integrated operations increased capacity by better matching rail flows to terminal inventories and more reliable vessel arrivals.

The involvement of the buyers in the innovation process was important for two reasons. First, shifting expectations to a more reliable supply chain and loading rates, discouraged producers and buyers entering into contracts geared to peak capacities; throughputs that too often turned out to be unrealistic. Second, as sales are dominantly on FOB terms, the buyers enter into the charterparty terms with the vessels used and arrange for contract provisions related to demurrage satisfactory to the vessels and exporters. However, contract provisions are confidential. The vessels are required to adhered to the information requirements and procedures of the NPA.

In 2009, consistent with, but outside, the framework agreement, NPA commenced to manage coal vessel movements and anchorage under the Vessel Arrival System (VAS). VAS does not apply to other vessels. Under VAS, the port uses TerraVision technology to monitor vessel movement from 15 days out to ascertain the reliability of the vessels estimated time of arrival (ETA). When NPA is confident of a vessel's progress, usually 7 days out, a Notified Arrival Time (NAT) places the vessel in the coal loading queue. This has been taken as the Notice of Readiness (NOR) under most contracts as exporters and terminals trust NAT, the terminals maintain performance records of the ships calling and expect coal to be available for loading. In 2017-2019, 64\% of the arriving vessels did not anchor; 3 days was the average time for vessels that anchored. Preliminary results of an Australian Maritime Safety Authority study by DNV GL quantifying the effect of VAS on fuel consumption and GHG emissions indicate average voyage speeds fell by over $20 \%$, (by correspondence).

\section{CHALLENGES AND STRATEGIES TO REDUCE ANCHORAGE}

The most obvious factor leading to the implementation of VAS was the beaching of the Pasha Bulker. The political response and the industry acceptance of the need to reduce the risk of an environmental catastrophe in Newcastle are in contrast to the limited response to the concerns expressed about anchorage for the port of Vancouver. However, the conditions in Vancouver and Newcastle demonstrate that there are diverse conditions contributing to the adoption of innovations related to shipping and the anchorage of ships. Recognition of these conditions can contribute to the advancement of digitisation and progress for PCO in ports generally. Governance is examined first as the contrast between the governance regimes in Vancouver and Newcastle is profound and the regimes influence the perceptions and conduct of companies.

\section{Governance}

There are four dimensions of port governance that appear to differentiate anchorage strategy between Newcastle and Vancouver. They are: the level of local responsibility; the importance of the landlord role; the number of organisations involved in anchorage; and the openness of the port bodies to digitised information systems. 
It is appropriate to note that NPA is a state body while VFPA is a federal non-shareholder corporation. This might be relevant in two ways. First, it could be argued that its national affiliation affects VFPA's response to local issues, but there is no substantive evidence to support this. However, management might be restrained in criticism of other federal bodies such as Transport Canada with which they work. Second, it could be argued that the effectiveness of community concerns on government is most effective when the responsible government is local. This leaves open to question whether the beaching of the Pasha Bulker resulted in a major government-backed initiative because it was "local" or because it was a major event. (In both countries, formal safety investigations are by national bodies.) Nevertheless, experience in these ports suggests that the more local the responsibility, the more responsive that actions are to environmental concerns.

More tangible effects of governance are related to the mandate of the port authority, its response to that mandate and the structure within which it exercises its responsibilities. VFPA is a landlord port for whom the most demanding attention has been for landside connections. This is in keeping with the Canadian concern with railways. A primary concern in Australia, as an island state, has been on shipping although it only became the NPA's sole focus in 2014.

The landlord status of a port authority can give rise to circumstances that make innovations affecting logistics, including shipping, difficult. In a landlord port, the relationship between the port authority and shippers and terminal operators involves mutual and conflicting interests as well as potential distrust by tenants of the interests being served by initiatives of the port authority. The latter concerns are aggravated in Vancouver because of its diverse trades and the range of competitive conditions within the trades. In Newcastle, the dominance of the coal trade in the port's business mitigated concerns about the interests of the NPA.

It is much easier to introduce change in a simple rather than a complex framework. In Newcastle, responsibility for services to shipping in coastal waters resides in practice with NPA alone. In Vancouver, it is split four ways; VFPA, TC, PPA, CCG. Also, the lead organisation for shipping is TC which is located in Ottawa, some 3,500 kms distant, and which does not have a good maritime tradition.

A port authority is commonly expected to be a leader, an innovator of change in port logistics. NPA, being a NSW corporation, played a lead role in negotiations for the Hunter Valley coal chain and has been a leader in the adoption of technology enabling VAS. VFPA's focus has been as a landlord. It has followed the policy since the 1980s of not engaging in community information systems, then electronic data interchange. It has subsequently adopted technologies in selected areas, for example, to support the Supply Chain Visibility Program. However, even in this sphere, initiatives in the bulk trades have been hindered by the diversity of trades and the heterogeneity of competing interests. No national pressure exists to change as Canada has not met its 2019 obligation under the Convention on Facilitation of International Maritime Traffic to implement electronic exchange of information in ship-to-shore communications.

\section{Trade Structure}

There are two major differences between the trade structure in the two ports; the diversity of trades and the relationships among the companies in each logistics chain. The diversity in the trades is obvious in the commodity mix. It has two implications for anchorage. The first is that the VFPA sees the diversity as inhibiting it from initiating measures to reduce anchorage as these would be seen differently by its clients. The second is that the incidence of anchorage varies greatly among the commodity trades. While the different geographies, seasonality of production and the terminals used affect logistics, it is the contrasted governance structures of the logistics of the trades that appear to be a crucial dimension affecting anchorage.

The governance structure has two separable components. The first is the terms of shipment which in Vancouver has a material effect on the scheduling of ships and on the commencement and quality of information exchanged between the terminal/shipper and the ship. Sales on delivered (CFR) terms, as is usual for potash, enable the best integration of vessel arrival and terminal readiness. However, effective planning and communication under FOB terms is possible so that vessels schedules could be reliable. However, too often the actual schedule of vessel arrivals is to meet the supply chain needs of buyers and the timing of vessel arrival is to serve the interests of vessels under its charterparty terms.

A critical issue under FOB terms is the incentive for vessels to arrive early in the laycan time window. A delayed arrival within this window reduces the probability of demurrage which can be expected to have a greater daily value than fuel saved from slow steaming. Therefore, the incentive for ships to arrive early in laycan increases with the probability that demurrage will be paid.

Newcastle has broken the race-to-wait cycle. It has increased the probability of berth availability consistent with the Notified Arrival Time (NAT) given under VAS and usually accepted by shippers as the Notice of Readiness (NOR). The greater probability of on-time loading reduces the incentive for ships to race and the reluctance of shippers to accept an early designation of NOR. The participation of buyers as charterers of ships is important to the system although the details of charterparty terms are confidential. Achieving participation of buyers and sellers is essential to efforts to reduce anchorage, including by the VA clause.

In an FOB sale, a voyage charterparty is negotiated between the buyer and the shipowner, yet in the loading port it is the exporter that bears the cost of demurrage. Consequently, there are three major interests in the charterparty terms, which are made weeks or months before fuel costs and likely delays are known. There are only two parties involved under FOB contracts at a discharge port. The number of parties involved is reversed under CFR contracts. The challenges created by the three-party involvement in virtual arrival arrangements is a serious impediment to the introduction 
of VA. It has not received recognition in the literature reviewed for this paper. Nor is there any evidence that shippers in Vancouver have attempted to engage in discussions of VA with buyers. VA is perceived as inapplicable to Vancouver's trades.

Factors excluded from the decision structure described so far are the environmental costs of anchorage. These got factored into the NSW decision making indirectly thanks to the Pasha Bulker. The result has been a system beneficial environmentally and commercially. In Vancouver, environmental consequences are acknowledged but have affected anchorage only through the policy to distribute ship anchorage days "fairly" among locations in the Gulf Islands.

The second aspect of trade structure is in domestic logistics. The more integrated the process, the greater the visibility which enables enhanced predictability and response to dynamic conditions. The Hunter Valley coal chain is exceptional in the level of integration enabled by the framework agreement with the consequent reliability of terminal inventory. The Vancouver product chains vary with the least integrated being grain. The performance of all chains is still adversely affected by relationships between shippers and the railways. They have still not overcome a long history of adversarial relationships over freight rates that still adversely affects the integration of rate and service quality management into efficient partner relationships.

The differences across the commodity and company logistics in Vancouver means that the potential benefits from innovations to reduce anchorage are uneven. A company with a system that it believes is better than that of others may see little benefit, offset by concern for possible exposure of its practices and a loss of competitive advantage. Different positions were evident among producers in the Hunter Valley coal chain, however, all parties benefited. The outcomes from the performance of that chain and the comparison of performance across the commodities in Vancouver carry some general lessons.

\section{General Lessons and Potential Strategies}

Features of port governance and the diverse commodity trades with their differentiated structures pose challenges in Vancouver that were largely absent in Newcastle. Nevertheless, the experience of Newcastle can be used to suggest strategies to enable reduced anchorage for Vancouver's trades and, perhaps, for other ports.

Arguably, the most significant lesson from Newcastle is the successful monitoring of vessels from 14 days out, enabling the implementation of VAS. This is in sharp contrast to the $24 \mathrm{~h}$ notice of arrival for VFPA. The NPA assigns ships a NAT. The VFPA assigns ships to an anchorage. It appears that the accuracy of NAT and NOR under the VAS system, knowledge that the ships will be ready to load and that the terminal will be ready to accommodate them have resulted in a viable system that have existed for over a decade. In Vancouver, such a system would be most likely but least beneficial in the potash trade; a challenge but highly beneficial in the coal trade; and least likely but most beneficial in the grain trade. The party that monitors vessel progress and assigns a NAT does not have to be the port authority. However, there would likely be concerns for other parties in a chain if any one of them had vessel tracking and arrival timing authority. The Newcastle experience demonstrates advantages of VAS. It does not suggest an acceptable trigger to stimulate change; a ship on the beach is not acceptable!

A potential initiative for the VFPA in the interest of environmental protection and safety would be to initiate a strategy to require any vessel coming to Vancouver to provide and update its ETA from at least 7 days out. Such a measure would not directly affect the demand for anchorage but it would enable safer and more efficient allocation of vessels to anchorages to the benefit of all trades. Also, it should be a positive step in the digitisation of port-ship communications.

The second general lesson is that in a network the benefits from greater reliability in links can compound. More reliable performance at an early section of a chain enables improvements to take place in later sections. Also, there are economies of scope across chains in interlocked networks which may be positive or negative; for example, in access to anchorages. They can be positive if more efficient demand for capacity for one chain frees resources for others. They can be negative if a changed pattern of demand adversely affects services available to others. Such effects are more complex for rail than for maritime services but are likely to be positive.

In Newcastle, the involvement of players along the entire chain enabled better connectivity and reduced uncertainty in the performance of the mine, rail, terminal and shipping components of the chain. All segments benefit. In Vancouver, the multiple commodity and container chains are networked in their common use of the capacity provided in rail and maritime services. The implication is that while an initial focus on individual commodity chains is likely, the evaluation of change should take network effects into account.

Finally, Newcastle exemplifies the value of collaborative relationships involving participants in the full logistics chain, relationships that facilitate the use of digitised communication. For Vancouver to advance its performance, more collaboration is necessary along and across the commodity chains. A step in this direction might be achieved by a commodity pilot project demonstrating the value of digitised transactions for one or more vessel visits.

There are four possible benefits from such a demonstration project. The first is derived from establishing the need to identify and overcome the technical challenges in linking the communications systems across the enterprises involved; the ship, PPA, VFPA, ship agents and terminals. The second is that it would likely, but not necessarily, involve charterers, thereby opening the door for more communications. The third is the opportunity to identify critical system components that affect JIT performance. For example, the pilot ordering regime may be vital, since a vessel can not move within the pilotage area without a pilot. The fourth is the least tangible but may be the most important; to change perceptions and attitudes to the adoption of digitisation which may have long-run consequences for port logistics. It would demonstrate that the technical capacity is here, it is the behavioural innovation that lags. 


\section{DATA AVAILABILITY STATEMENT}

The raw data supporting the conclusions of this article will be made available by the authors, without undue reservation.

\section{REFERENCES}

ACCC (2009a). Determination in Respect of PWCS Tonnage Allocation. Available at: https://www.accc.gov.au/system/files/public-registers/documents/D09\% 2B46763.pdf (Accessed October 2, 2020).

ACCC (2009b). Determination in Respect of the Capacity Framework Arrangements at the Port of Newcastle. Available at: https://www.accc.gov. au/system/files/public-registers/documents/D09\%2B193856.pdf (Accessed March 28, 2021).

ATSB (Australian Transport Safety Bureau) (2008). Marine Occurrence Investigation No. 243, Grounding of the Pasha Bulker. Available at: https:// www.atsb.gov.au/media/1362985/mair243_001.pdf (Accessed March 10, 2020).

BIMCO (2021). Just in Time Arrival Clause for Voyage Charter Parties 2021, BIMCO Clauses. Available at: https://www.bimco.org/contracts-and-clauses/ bimco-clauses/current/just-in-time-arrival-clause-for-voyage-charter-parties2021 (Accessed February 22, 2021).

BIMCO (2013). Virtual Arrival Clause for Voyage Charter Parties 2013. Available at: https://www.bimco.org/contracts-and-clauses/bimco-clauses/current/virtual_ arrival_clause_for_voyage_charter_parties_2013 (Accessed June 16, 2020).

Broad, A., Rees, M. J., and Davis, A. R. (2020). Anchor and Chain Scour as Disturbance Agents in Benthic Environments: Trends in the Literature and Charting a Course to More Sustainable Boating and Shipping. Mar. Pollut. Bull. 161, 111683-111713. doi:10.1016/j.marpolbul.2020.111683

Bruijn, D. (2021). We Need to Expand Just-In-Time Arrivals beyond Containerships. Tradewinds. Available at: https://www.tradewindsnews.com/ opinion/we-need-to-expand-just-in-time-arrivals-beyond-containerships/2-1959184 (Accessed February 22, 2021).

Canadian National Railway (2006). Annual Report. Available at: https://www. annualreports.com/HostedData/AnnualReportArchive/c/TSX_CNR.TO_2006. pdf (Accessed January 25, 2021).

Davey, O., Button, M., and Leitch, A. (2021). Resilience4Ports. Available at: https:// www.resilienceshift.org/resilience4ports/ (Accessed March 26, 2021).

GIA (2020). Reduction of GHG Emissions from Ships, Just in Time Arrival Guide Barriers and Solutions. Note by the Secretariat, MEPC 75/INF.22. Available at: https://sustainableworldports.org/wp-content/uploads/MEPC-75-INF.22-JustIn-Time-Arrival-Guide-Barriers-and-Solutions-Secretariat.pdf (Accessed January 25, 2021).

Golias, M. M., Saharidis, G. K., Boile, M., Theofanis, S., and Ierapetritou, M. G. (2009). The Berth Allocation Problem: Optimizing Vessel Arrival Time. Marit Econ. Logist 11 (4), 358-377. doi:10.1057/mel.2009.12

Hamburg (2019). How Technology Empowers Leading Ports, Hamburg Port Authority. Available at: https://www.hafen-hamburg.de/en/news/ interconnectivity-artificial-intelligence-cyber-resilience-how-technology-empowersleading-ports-chainport-concludes-5th-annual-meeting-in-montreal-36472 (Accessed June 10, 2020).

Hensel, T., Ugé, C., and Jahn, C. (2020). Green Shipping: Using AIS Data to Assess Global Emissions. NachhaltigkeitsManagementForum 28, 39-47. doi:10.1007/s00550-020-00498-x Available at: https://link-springer-com. ezproxy.library.ubc.ca/article/10.1007/s00550-020-00498-x (Accessed January 11, 2021).

IMO (2020). Reduction of GHG Emissions from Ships, Just in Time Arrival Guide - Barriers and Solutions. Note by the Secretariat, MEPC 75/INF.22. Available at: https://sustainableworldports.org/wp-content/uploads/MEPC-75-INF.22Just-In-Time-Arrival-Guide-Barriers-and-Solutions-Secretariat.pdf (Accessed January 11, 2021).

Inbakaran, R., Chhetri, P., Sorbello, S., and Ding, M. (2008). Managing Supply Chain Disruptions: A Case Study of Hunter Valley Coal Chain. Available at: https://scholar.google.ca/scholar?q=Managing+Supply+Chain+Disruptions: $+\mathrm{A}+\mathrm{Case}+$ Study+of + Hunter+Valley+Coal+Chain+NSW+Australia\&hl=en\&as sdt=0\&as_vis=1\&oi=scholart (Accessed June 10, 2020).

\section{AUTHOR CONTRIBUTIONS}

The author confirms being the sole contributor of this work and has approved it for publication.

INTERTANKO (2011). Virtual Arrival: Optimising Voyage Management and Reducing Vessel Emissions - an Emissions Management Framework. Available at: https:/www. ocimf.org/media/115960/Virtual-Arrival.pdf (Accessed June 15, 2020).

Islands Trust (2018). Islands Trust Calls on Ottawa to Reduce and Ultimately Eliminate Freighter Anchorages. Available at: https://islandstrust.bc.ca/wpcontent/uploads/2020/06/2018-10-it_anchorages-statement_final.pdf (Accessed June 16, 2020).

Jahn, C., and Scheidweiler, T. (2018). Port Call Optimization by Estimating Ships' Time of Arrival. Cham, Switzerland: Springer, 172-177. doi:10.1007/978-3-319-742250_23 Available at: https://link.springer.com/chapter/10.1007/978-3-319-74225-0_23 (Accessed January 11, 2021).

Jia, H., Adland, R., Prakash, V., and Smith, T. (2017). Energy Efficiency with the Application of Virtual Arrival Policy. Transportation Res. D: Transport Environ. 54, 50-60. doi:10.1016/j.trd.2017.04.037

Johnson, H., and Styhre, L. (2015). Increased Energy Efficiency in Short Sea Shipping through Decreased Time in Port. Transportation Res. A: Pol. Pract. 71, 167-178. doi:10.1016/j.tra.2014.11.008

Kontovas, C. A., and Psaraftis, H. N. (2013). Bridging the Energy Efficiency Gap in Shipping: The Case of Principal-Agent Problems in Operational Emission Reduction Measures. Marseille: International Association of Maritime Economists Conference, 20. By corespondence.

Legato, P., and Mazza, R. M. (2020). Queueing Analysis for Operations Modeling in Port Logistics. Maritime Business Rev. 5 (1), 67-83. doi:10.1108/MABR-092019-0035

Lind, M., Haraldson, S., Karlson, M., and Watson, R. T. (2016). Overcoming the Inability to Predict - a PortCDM Future, 10th IHMA Congress - Global Port \& Marine Operations, 30th May - 2nd May 2016, Vancouver, Canada.

Oz, D., Aksakalli, V., Alkaya, A. F., and Aydogdu, V. (2015). An anchorage Planning Strategy with Safety and Utilization Considerations. Comput. Operations Res. 62, 12-22. doi:10.1016/j.cor.2015.04.006

Poulsen, R. T., and Sampson, H. (2020). A swift Turnaround? Abating Shipping Greenhouse Gas Emissions via Port Call Optimization. Transportation Res. Part D: Transport Environ. 86, 1-13. doi:10.1016/ j.trd.2020.102460

Poulsen, R. T., and Sampson, H. (2019). 'Swinging on the Anchor': the Difficulties in Achieving Greenhouse Gas Abatement in Shipping via Virtual Arrival. Transportation Res. Part D: Transport Environ. 73, 230-244. doi:10.1016/ j.trd.2019.07.007

Pynn, L. (2018). Freighter in Paradise, Hakai Magazine. Available at: https://www. hakaimagazine.com/news/freighters-in-paradise/ (Accessed March 5, 2021).

Rehmatulla, N. (2012). Barriers to Uptake of Energy Efficient Operational Measures Survey Report UCL Energy Institute. Available at: https:// discovery.ucl.ac.uk/id/eprint/1450794/2/Rehmatulla\%20\%282012\%29\%20Low \%20Carbon\%20Shipping\%20Survey\%20report.pdf (Accessed March 6, 2021).

Rohner, C., and Fullerton, T. (2020). Ship Congestion at the Port of Vancouver and Southern Gulf Islands. Centre for Marine Affairs, southern Gulf Islands. by correspondence. Available at: https://marineaffairs.ca/reports/anchorage-shipcongestion-rohner-fullerton-2020.pdf.

STM (2021). About Sea Traffic Management. Available at: https://www. seatrafficmanagement.info/about-stm/ (Accessed January 20, 2021).

STM (2017). PortCDM - Information Sharing in Real Time, Sea Traffic Management. Available at: https://www.seatrafficmanagement.info/news/ portcdm-information-sharing-in-real-time/ (Accessed January 20, 2021).

Tardif, L-P. (2010). Measuring Supply Chain Performance. Toronto: APCGI workshop. Available at: https://fdocuments.in/document/measuring-supplychain-performance-a-supply-chain-performance-a-government.html (Accessed March 10, 2021).

Transport Canada (2018). Interim Protocol for the Use of Southern B.C. Anchorages. Available at: https:/www.tc.gc.ca/en/services/marine/portsharbours/interim-protocol-use-southern-bc-anchorages.html (Accessed June $5,2020)$. 
Transportation Research Board (2018). Workshop on Implementing a Freight Fluidity Performance Measurement System. Circular Number E-C240. Available at: http:// onlinepubs.trb.org/onlinepubs/circulars/ec240.pdf (Accessed January 20, 2021).

TSB (2021) This Work Was Supported by the Social Sciences and Humanities Research Council of Canada, Green Shipping Partnership [Grant No. 8952017-1003].

UNCTAD (2020). Digitalizing the Port Call Process. Geneva: Transport and Trade Facilitation Series NO.13. Available at: https://unctad.org/system/files/officialdocument/dtltlb2019d2_en.pdf (Accessed March 9, 2021).

Wärtsilä (2020). Successful Application of Wärtsilä Navi-Port. Available at: https:// www.wartsila.com/media/news/19-02-2020-successful-application-of-wartsilanavi-port-highlights-benefits-of-just-in-time-sailing-2642817 (Accessed October $1,2020)$.

Waters, W. G. (1973). Landing a Man Downtown. Bull. At. Scientists 29 (9), 34-35. doi:10.1080/00963402.1973.11455530

World Bank (2020). Accelerating Digitalization, Mobility and Transport Connectivity Series. Available at: http://pubdocs.worldbank.org/en/773741610730436879/ Accelerating-Digitalization-Across-the-Maritime-Supply-Chain.pdf (Accessed March 4, 2021).

WPSP (2020). Port and Shipping Industry Partners in Urgent Call to Action to Accelerate Pace of Digitalization to Cope with a post-COVID19 "New normal". Available at: https://sustainableworldports.org/port-and-shipping-industry-partnersin-urgent-call-to-action-to-accelerate-pace-of-digitalization/ (Accessed March 5, 2021).
Zhong, M., and Ai, W. (2017). Discussion on the Planning and Design Elements of the Sheltered Anchorage. Adv. Eng. Res. 153, 254-257. Available at: https:// www.atlantis-press.com/proceedings/aetr-17/25892843 (Accessed January 14, 2021).

Zion Market Research (2021). Vessel Traffic Management Market. Available at: https://www.zionmarketresearch.com/report/vessel-traffic-management-market (Accessed January 20, 2021).

Conflict of Interest: The author declares that the research was conducted in the absence of any commercial or financial relationships that could be construed as a potential conflict of interest.

Publisher's Note: All claims expressed in this article are solely those of the authors and do not necessarily represent those of their affiliated organizations, or those of the publisher, the editors and the reviewers. Any product that may be evaluated in this article, or claim that may be made by its manufacturer, is not guaranteed or endorsed by the publisher.

Copyright (C) 2021 Heaver. This is an open-access article distributed under the terms of the Creative Commons Attribution License (CC BY). The use, distribution or reproduction in other forums is permitted, provided the original author(s) and the copyright owner(s) are credited and that the original publication in this journal is cited, in accordance with accepted academic practice. No use, distribution or reproduction is permitted which does not comply with these terms. 